\title{
Historical Silahtaraga Power Plant-Black Sea Decovil Line Research, Double Military Decovil Photogrammetry Study
}

\author{
Cemal İrfan Çalışkan* \\ Industrial Designer, Fatih Sultan Mehmet Vakif University, Türkiye
}

*Corresponding author: Cemal İrfan Çalışkan, Industrial Designer, Fatih Sultan Mehmet Vakif University, Istanbul, Türkiye

\begin{abstract}
In this article, which we prepared in addition to the works carried out by tracing a lost cultural heritage, In 1915 Turkish geography, investigation and photogrammetry study on the narrow-gauge railroad line built to transport coal from the Black Sea coast to the Golden Horn will be included. In the study, a CAD model created by measurements made from old photographs related to the subject will be used as data in the prototype to be produced by SLS (Selective Laser Sintering) method. Then, we believe that the miniature model and production adventure of the Decovil locomotive, which we have brought to the present with the noncommercial serial production of the model, will be the means of remembering at least a cultural heritage that has not reached today.
\end{abstract}

Keywords: Cultural Heritage; Photogrammetry; Additive Manufacturing; Double Military Decovil

\section{Introduction}

In this part of the study, the research of the historical railway and its archaeological importance will be shared. In this review, news published on the internet pages and books and some collection materials prepared by the researchers were used. The narrow-gauge railroad line located in the boundaries of Istanbul, in Kagithane district was founded in 1915. In order to uncover the lost story of this railway which ended in 1950 with the dismantling of the rails, a book published named "100 years later on the trail of a lost railway". In the study carried out by the Municipality of Kagithane as a multi-disciplinary team, the team of writers created an important task in bringing the cultural heritage to the present day by bringing together the written documents, photographs and pieces of the railway which have the chance to reach today.



Figure 1: Kagithane dekovil line installation works (from Emre Dolen Collectio n) [4]. 
In the studies, many details related to the narrow-gauge railroad line, which was built for the purpose of transporting coal from the lignite basin in Agacli (25 km area starting from Kilyos to the Terkos Lake on the Black Sea coast) to the power plants in the Golden Horn, have been delivered to our day[1]. If we need to share some valuable details about the railway: The KagithaneBlack Sea decovil line, which was effectively used to meet energy needs during the First World War, was built between 1914 -1916 and is $57 \mathrm{~km}$ long (Figure1). The distance between the rails of the railway is $60 \mathrm{~cm}$ and this system is called as decovil [2]. The name dekovil comes from the company founded in 1875 of the surnames of the French engineer and businessman Paul Decauville who lived between $1846-1922$ [3].



Figure 2: Nowadays it is used as industrial archaeology museum [4].

The period when the line was established, World War I continues in the region. There is an energy problem in Istanbul due to the imports of coal stopped from the UK due to the war and the damage of ships bringing coal from Zonguldak to the region during the war. The fact that the Canakkale Strait was closed due to the war made it impossible to import coal through the Mediterranean. In the Ottoman geography of the period, coal was used as an energy source in ships and power plants rather than domestic fuel. Today it is a museum building; the building, known as Silahtaraga Power Plant of the period, meets the electricity needs of Istanbul (Figure2).

With the planned decovil line, it is aimed to evaluate the coal reserve on the Black Sea coast and to transport it to the Silahtaraga Power Plant without the need for sea transportation. In this way, the solution to the energy problem of Istanbul will be produced. Although the existence of the coal reserves of Agacli, Ciftalan region on the Black Sea coast has been known since the Byzantine Period, no studies have been conducted to make the reserve available for use. After the preliminary investigation, it is determined that the desired yield can be obtained by mixing the lignite coal in the region with Zonguldak hard coal, and it is decided to use the coal in the region and construction of the decovil line is started. The entire installation works are photographed by Hasan Mukadder Dolen, the railway regiment officer of the period.



Figure 3: Unloading of locomotives (source: war magazine, June 1916) [1]. 
Hasan Mukadder Dolen's photo collection was left to his grandson Emre Dolen after his death in 1975. It is known that many photographs and information about the historical railway have survived through this channel. Following the first line completed in 1915, a second line was built in Ciftalan in 1916. Railway rails and locomotives produced by Germany's decovil line, with many stations, vehicles and employees is important in terms of energy logistics of the period. It is mentioned in the historical documents that the rails and locomotives transported from Germany to the Ayestefanos Railway Regiment warehouses in Yesilkoy by the Danube River were later brought to Eyup, Silahtaraga by ships (Figure3).

The first line starts from Silahtaraga and reaches Agacli village after Kagithane stream; the other line runs through the Belgrade forests to the village of Ciftalan. The light rail line that reached the Black Sea coast from Kagithane, which is the famous promenade of the period, undertook an important duty in coal transportation during the years it was established, but was forgotten by being out of use in time.

The line was transferred to the Ministry of Commerce in 1922 and to the Ministry of Economy after the proclamation of the Republic [4]. Although traces of the line disappeared in the region after 1956, the rails remained largely underground and in many regions the rails were removed. It is known that one of the locomotives is currently located in the Celtek coal mine depot of the Special Provincial Administration of Amasya. In the photogrammetry study for the protection of cultural heritage, CAD model will be created by using original photographs of locomotives known as Zwilling Heeres Feldbahn (Double Military Decovil) produced in Munich in 1890 by Krauss Werkshof [1] (Figures 4 \& 5). The first prototype of the model produced with SLS (Selective Laser Sintering) one of today's 3d print technologies, will be used for silicon mould technique in mass production.



Figure 4: Double Military Decovil at Enver Pasha Station [1].

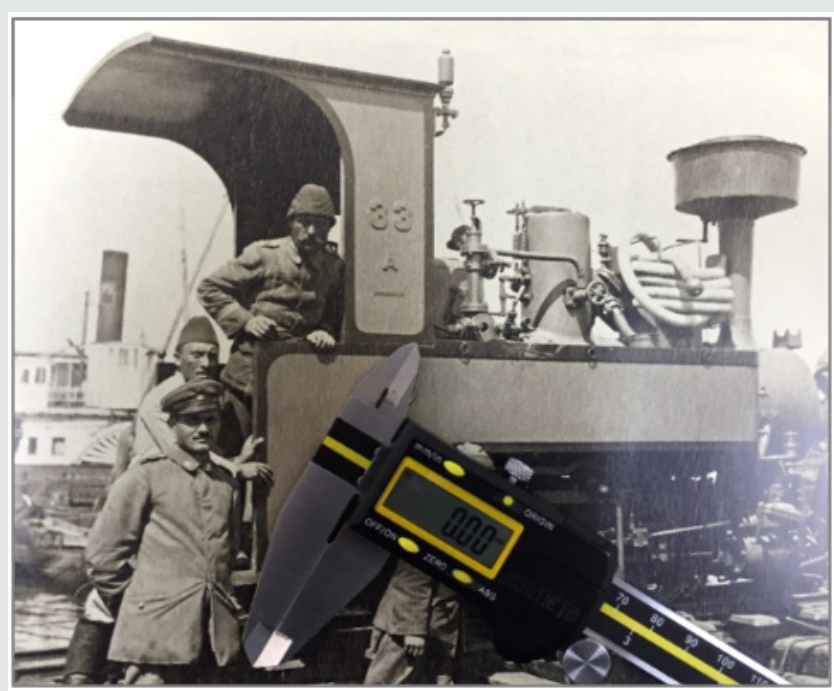

Figure 5: Photograph of the details of locomotive used in modelling studies [1]. 


\section{Literature on Photogrammetry}

In this part of the article, the photogrammetry study carried out with measurements taken from photographs of locomotives used in historical railway will be shared. In this context, sharing of literature knowledge about photogrammetry and its usage areas and then modelling study were included in the study. Visual analysis techniques are used in many scientific research areas. In the fields of anthropology and sociology, from the use of photographs of past periods [7] to airborne imaging technologies[8]; visual analysis techniques in different scientific fields from ecology, geography to medical science [9], are basically based on the use of photography as a source of information. Photographs used as data in the social field allow interpretations, social-cultural determinations and visual analysis of the time of the photograph [10]; in technical fields, it can also be used as a digital data source.

The use of photography for numerical data acquisition will be explained within the framework of photogrammetry concept. The word, which consists of a combination of ancient Greek "photos" (light), "grama" (drawing) and "metron" (measurement), means measuring with the help of pictures. Photogrammetry, which is used only in mapping, has been used in different areas in the following years. Basically, the photographic analysis to determine the shape, size and position of an object is called photogrammetry [11]. Photogrammetry is divided into three main sections (topographic photogrammetry, interpretation photogrammetry, special purpose photogrammetry) according to the application areas. Photogrammetry used in the fields of architecture, dentistry and archaeology is included in this third group [12].

In recent years, many studies have been done to document the cultural heritage with photogrammetric methods [13], photogrammetry has been used extensively in histor ical works documentation and model formation processes [12]. In such studies, the measurements taken on the photos allow the creation of the 3-D model of the historical work on the computer with digital photogrammetric techniques [14]. While the measurement process is carried out with the points and lines determined by the software, different methods can be used. In our study, the CAD model, which is designed with the measurements with calliper and ruler from old photographs, will be discussed within the scope of special-purpose photogrammetry.

\section{Modelling Process}

In this part of our study, we will discuss the modelling process created by taking measurements from the historical photographs of the railway line locomotive of Kağithane. In the modelling study, the locomotive CAD model was created in CATIA V5. The modelling; cabin, nose, mechanical parts and rails, including a total of 4 body consists of (Figure 7).



Figure 6: Binary military narrow-gauge railroad locomotive technical drawing, one of the technical drawings of Alan Prior in the book (100 years later on the trail of a lost railway) [1].

Part design tools are used in the modelling. The modelling of the locomotive as 4 bodies is taken into consideration for the production criteria for the silicone mould to be needed during mass production. In this sense, the model has been modelled and divided into pieces so as to enable post-production assembly. In the modelling study, first the technical drawings (Figure 6) made by Alan Prior were used for general information about the model; in the detail drawings, black and white photographs taken from different angles were used. After the results of modelling, some forms are very detailed for the casting process and line softening is performed according to the model casting process (Figure 7). 



Figure 7: Different colours of the locomotive parts that can be used as 4 different bodies.

\section{Data Transfer to 3d Printing System After Modelling}

(STL File, Quality Problems) STL (Stereolithography) data is needed for additive manufacturing of the model. The CAD data generated for this reason is exported in the STL format in the CATIA software. In this process, STL mesh quality is important for the surface quality of the model to be produced. The quality of the prototype to be produced with SLS will affect the quality of the silicone mould from this prototype. The quality problems in the STL data are related to the number of mesh on the surface and the settings of the CATIA display and the necessary arrangement is made as follows: First, the screen settings are set in the "tools" "options" - "performance" section in the top menu of the CATIA Part Design module. In this section, the 3D Accuracy and 2D Accuracy "fixed" values are revised to " 0.01 ". The value 0.01 remains constant until changed again.

The next editing is done in the CATIA STL Rapid Prototyping module. In the "tesselation" command, with "sag" value, $0.001 \mathrm{~mm}$ and "grouped" option preference, the mesh quality of each part is determined (Figure 8: on the effect of mesh quality adjustment on surface quality in STL data).


Figure 8: STL view (on the left) before the quality correction, STL view after tesselation and performance correction (on the right).

\section{Model Production Process}

The technique used in the prototype production is SLS (Selective Laser Sintering) and the material used is PA 2200 (polyamide). If we need to give basic information about SLS production system: The SLS technique is made by sintering micron-size polymer powder in layers, using laser power. In 1986, Carl Deckard, a student at the University of Texas, developed this method of powdered material, which he called PGLSS (Part Generation by Layer wise Selective Sintering). Later on, this production technique called SLS, (with the description text: computer-aided laser apparatus which sequentially sinters a plurality of powder layers to build the desired part in a layer-by-layer fashion) is patented on October 1986 [15]. The method of SLS production is as follows:
Firstly, files saved in STL format are opened in Netfabb software and settled in the production area. (Figure5). All parts are sliced at intervals of $0.1 \mathrm{~mm}$ (100 microns) after placement. Then the file sliced into 100 microns is saved in SLI format. Although there are 60 microns slicing options within the system, 100 microns will be sufficient for the desired quality. Then the process will continue in the EOS PSW software. After the material preference and parameter selection in EOS PSW software, the file will be transferred to the production bench. The material preference is selected as PA2200 and the layer thickness is 100 microns. The production parameter is then determined. After the prototype production to be performed in EOS P110 (Figure 9), silicone moulding will be carried out for mass production. 



Figure 9: Positioning of the parts in the Netfabb software before production (on the left). Parts mounted after SLS production will be used for silicone moulding (on the right).

The first prototype produced with PA 2200 material, is used to form the silicone mould. After that, the model which is replicated in the manufacturer company by casting process from polyester material is painted with handwork and the final product is obtained (Figure 10). In classical applications, the silicone mould is taken from the prototype modelled by the sculptor and polyester casting process is performed. In the prototype production subject to our study, the process was completed by using digital technologies and methods. In the study, modelling was performed in parametric cad software, enabling the revisions needed in the process to be made quickly.


Figure 10: Parts made of polyester cast technique (on the left), the locomotive models completed by hand paint after polyester production (on the right).

\section{References}

1. Emre Dölen ȘS,Mert Sandalcı, Hüseyin Irmak, Alan Prior (2015) 100 yıl sonra kayı bir demiryolunun izinde- 100 years later on the trail of the lost railway. ( $1^{\text {st }}$ edn) İstanbul: Kağıthane Belediyesi.

2. Demiryolu.net (2016) "Tarihi Demiryolu Hattı Yeniden Hayata Geçiyor".

3. Paul Decauville.

4. dunyabulteni.net (2014) "istanbul'daki kayıp demiryolu gün yüzüne çıktı".

5. "santralistanbul".

6. haberler.com (2016) "Haliç-Kemerburgaz Arası Tarihi Tren Hattı Hayata Geçiyor".

7. Hartel J, Thomson L (2011) Visual approaches and photography for the study of immediate information space. J Am Soc Inf Sci Technol 62(11): 2214-2224

8. Eisenbeiss H (2009) UAV Photogrammetry: A dissertation submitted to ETH ZURICH for the degree of Doctor of Sciences-Zürich: ETH pp. 203.
9. Basil M (2011) Use of photography and video in observational research, Qual Mark. Res An Int J 14(3): 246-257.

10. Spencer S (2010) Visual research methods in the social sciences: Awakening visions. Routledge.

11. Duran Z, TOZ G (2010) Tarihi eserlerin fotogrametrik olarak belgelenmesi ve coğrafi bilgi sistemine aktarılması. iTÜDERGiSi/d 2(6).

12. Güleç SA (2007) Yersel fotogrametri yöntemi ile rölöve alım tekniğinin taç kapılarda uygulanışı-Konya örnekleri. Selçuk Üniversitesi Fen Bilimleri Enstitüsü p. 66.

13. Andreu J, Serrano P (2019) Contributions of the digital photogrammetry and 3D modelling of Roman inscriptions to the reading of damaged tituli: An example from the Hispania Tarraconensis (Castiliscar, Saragossa). Digit Appl Archaeol Cult Herit 12: e00091.

14. Bitelli G, Girelli VA, Marziali M,Zanutta A (2007) “Use of historical images for the documentation and the metrical study of cultural heritage by means of digital photogrammetric techniques," in XXI International CIPA Symposium, Athens, Greece.

15. Shellabear M, Nyrhilä O (2004) “DMLS-Development history and state of the art," Laser Assist. Netshape Eng 4, Proc $4^{\text {th }}$ LANE pp. 21-24. 

(C) Co This work is licensed under Creative

To Submit Your Article Click Here: Submit Article

DOI: $10.32474 / J A A S .2019 .01 .000102$

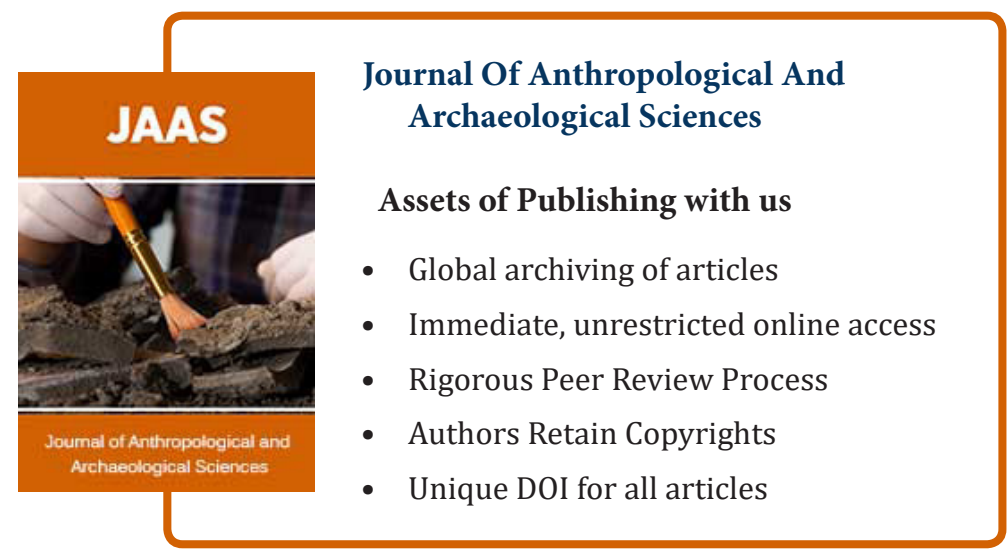

